\title{
Chromosome Numbers in the Chilean Endemic Genus Leucocoryne (Huilli)
}

\author{
Loreto Araneda, Paulina Salas, and Leví Mansur ${ }^{1}$ \\ Department of Agronomy, Pontificia Universidad Católica de Valparaíso, Quillota, Chile
}

AdDitional INDEX words. Glory of the Sun, chromosomes

\begin{abstract}
Few cytological studies have been conducted on the endemic Chilean genus Leucocoryne, which is comprised of 14 species and a number of populations whose taxonomy has not been elucidated. Eleven species/populations of Leucocoryne have been examined cytologically and L. ixioides (Hook.) Lindl., L. coquimbensis var coquimbensis F.Phil., $L$. narcissoides R. Phil., $L$. sp. 'Alcones', $L$. sp. 'Talinay' and $L$. sp. 'Combarbalá' were observed to be $2 n=18 ; L$. purpurea Gay, $L$. sp. 'Ñague', $L$. sp. 'Alicahue' and $L$. sp. 'Pichicuy' are $2 n=10$ and $L$. coquimbensis var alba had $2 n=14$. Furthermore, a natural hybrid population of $L$. purpurea and $L$. coquimbensis var coquimbensis had individuals with $2 n=14$ and $2 n=22$ chromosomes in addition to the normal complement of $2 n=10$ and $2 n=18$. The results indicate that Leucocoryne with the exception of $L$. coquimbensis var alba is typically either $2 n=10$ or $2 n=18$ with a similar number of species or populations at each ploidy level. Furthermore, the hybrid population demonstrated that there is gene flow between the species at different ploidy levels.
\end{abstract}

The genus Leucocoryne Lindley, is comprised of 14 species endemic to Chile (Zöellner, 1972), however, there are a number of distinct populations whose taxonomy has not been clearly defined (Mansur, 2002). In the past the genus was classified as Amaryllidaceae (Hutchinson, 1959 ), and later as Liliaceae (Engler, 1964$)$ ). However, currently it is included in the Alliaceae (Rahn, 1998).

Leucocoryne is particularly interesting from an ornamental point-of-view because of the high level of phenotypic variability as displayed in the various colors, forms, shapes and aromas of its flowers, long vase-life and for its potential use as a pot plant (Hayward, 1940; Kroon, 1989; Mansur, 2002; Ohkawa et al., 1996). It has been determined that Leucocoryne is largely self-incompatible, which could explain this variability (Mansur, 2002; Rojas and Mansur, 2001). The Department of Agronomy at the Pontificia Universidad Católica de Valparaíso, Chile, seeks to conserve ex situ, carry out scientific studies and genetically improve as ornamentals native geophytic species with Leисocoryne being its most advanced project. Currently, three varieties, for cut flower, are being registered with Chilean Ministry of Agriculture. Cytological studies have become necessary to plan crosses, investigate genetic flow between Leucocoryne species of different ploidy levels, characterize the materials in the collection, and assist in their taxonomic classification.

Eleven species of Leucocoryne have previously been examined cytologically and seven were observed to be $2 n=10$ and four $2 n=$ 18 (Bahamondes and Labarca, 1994; Cave, 1939; Crosa 1988).

The objective of this paper is to confirm the chromosomal number of five species previously reported: $L$. ixioides, $L$. coquimbensis var coquimbensis, L. narcissoides, $L$. purpurea and $L$. sp. 'Nague' (from Nague, Chile) and to determine chromosomal number of L. coquimbensis var alba and five new and distinct populations whose taxonomy remains undetermined. In addition genetic flow was investigated in a natural population of Leucocoryne whose putative parental lines are of different ploidy levels.

Received for publication 28 Apr. 2003. Accepted for publication 24 Sept. 2003.We thank Luis Arriagada for his assistance in collecting and Orfeo Crosa for his technical advice. This research was supported with funds from Fondo-SAG of the Servicio Agricola y Ganadero, Chile.

${ }^{1}$ Corresponding author; e-mail levi@entelchile.net.

\section{Materials and Methods}

The germplasm used in this research is listed in Table 1. If the population has been taxonomically classified then its species name is indicated (i.e., L. narcissoides); those not yet taxonomically classified are denoted as populations and they are listed as $L$. sp. followed by the name of the locations where they were collected (i.e., $L$. sp. 'Talinay'). For these populations, representative photographs of their flowers are presented in Fig. 1. Note that $L$. narcissoides was listed by Bahamondes and Labarca (1994) as Pabellonia incrassata (Quezada and Marticorena, 1976).

The regions where the species were collected correspond to the administrative division of Chile. There are 12 regions plus the Metropolitan Region around the capital of Santiago. Region I is at the extreme north (Atacama desert) and Region XII at the southern tip (Tierra del Fuego and Antártica).

Chromosome analysis: The root tips were obtained from bulbs sprouted on petri dishes at $15^{\circ} \mathrm{C}$. Seeds were germinated under the same conditions. Chromosome counts were made on six to ten metaphase cells of each species or population. These metaphase cells were chosen from meristematic cells of four or five root tips per bulb from each of three or four bulbs per species or population. Furthermore, the number of chromosomes in L. coquimbensis var coquimbensis, L. sp. 'Talinay', L. sp. 'Alcones', L. sp. 'Combarbalá', $L$. sp. 'Ñague', $L$. sp. 'Pichicuy' and $L$. ixioides were confirmed using root tips collected from germinating seeds of intraspecific crosses made by hand in a greenhouse. Root tips from six seeds of each species or population were used.

The squash technique described by Dyer (1963) and adapted for Leucocoryne by Crosa (1988) was used. Briefly this consisted of a fixing solution of 3:1 absolute methanol to acetic acid (glacial $100 \%$ ), and an orcein lacto-propionic dye. Before fixation, the root tips were pre-treated with a $0.05 \%$ colchicine aqueous solution for $20 \mathrm{~h}$ at room temperature. The karyotypes were based on the shape and length of each chromosome. Measurements were made using MicroMeasure version 3.3 software (http://www.colostate.edu/ Depts/Biology/MicroMeasure). The black and white photographs of the preparations were scanned and Paint Shop Pro 5 version 5.01 (Jasc Software, Inc.) was used to assemble the karyotypes (Figs. 2-4). Each chromosome was classified according to the terminology of Levan et al. (1964). 
Table 1. List of plant materials utilized in this investigation and the date of collection and place of origin.

\begin{tabular}{|c|c|c|c|c|c|c|}
\hline Species & Date & Regionz $^{z}$ & Province & City & Locality & Latitude \\
\hline L. narcissoides & 1997 & III & Huasco & Huasco & Llanos de Challe & $29^{\circ}$ South \\
\hline L. coquimbensis var alba & 1997 & IV & Elqui & Coquimbo & Las Tacas & $30^{\circ}$ South \\
\hline L. sp. Talinay & 1996 & IV & Limarí & Ovalle & Talinay & $30^{\circ}$ South \\
\hline L. sp. Alcones & 1997 & IV & Limarí & Ovalle & Alcones & $30^{\circ}$ South \\
\hline L. sp. Combarbalá & 2001 & IV & Limarí & Combarbalá & Combarbalá & $31^{\circ}$ South \\
\hline L. sp. Alicahue & 1996 & $\mathrm{~V}$ & San Felipe & San Felipe & Altos de Alicahue & $32^{\circ}$ South \\
\hline L. ixioides & 2001 & $\mathrm{~V}$ & Valparaíso & Quilpue & Quilpué & $33^{\circ}$ South \\
\hline
\end{tabular}

${ }^{2}$ Chile is divided in 12 Regions plus Santiago's Metropolitan Region (Administrative Division). Region I is at the northern extreme (Atacama Desert) and Region XII at the southern extreme (Tierra del Fuego and Antártica) of the country.

\section{Results and Discussion}

Our results confirm that Leucocoryne is comprised of two groups of species which are either $2 n=10$ or $2 n=18$ (Table 2 ; Figs. 2 and 3). The chromosome numbers reported previously by Bahamondes and Labarca (1994) for L. narcissoides as $2 n$ $=18, L$. coquimbensis var coquimbensis, as $2 n=18$ and $L$. sp. 'Ñague' as $2 n=10$, were confirmed (Figs. 2a and 3a-b). Also no discrepancies were observed with the karyotypes of $L$. ixioides $(2 n=18)$ and $L$. purpurea $(2 n=10)$ reported by Crosa (1988) (Figs. $2 \mathrm{~b}$ and $3 \mathrm{c}$ ). If we add $L$. conferta and $L$. angustipetala as reported by Crosa (1988) to the species or populations listed in Table 2 we observe that there is an equal number of species in each chromosome number group. Crosa (1988) postulated that the $2 n$ $=18$ group is a tetraploid formed by fusion of the two telocentric chromosomes of the $2 n=10$ species, followed by chromosomal doubling. Our data are insufficient to clarify this issue; however, we are preparing to analyze chromosome pairing during meiosis of crosses between these two groups in order to test that hypothesis.

On the other hand, $L$. sp. 'Pichicuy' and $L$. sp. 'Alicahue' (Fig. 2c and d) were $2 n=10$. L. sp. 'Pichicuy' had six metacentric chromosomes, two subtelocentric chromosomes and two telocentric chromosomes whereas $L$. sp. 'Alicahue' had the same number of metacentric chromosomes and four telocentric chromosomes. Furthermore, $L$. sp. 'Talinay', $L$. sp. 'Alcones' and $L$. sp. 'Combarbalá' (Fig. 3d,e and f) had a somatic number of $2 n=18$. Both $L$. sp. 'Talinay' and $L$. sp. 'Combarbalá' had a karyotype composed of 14 metacentric chromosomes, two subtelocentric chromosomes and two telocentric chromosomes. Surprisingly L. sp. 'Alcones' (Fig. 3e) presented two submetacentric chromosomes and two subtelocentric chromosomes.

We observed that a sample of seven individuals taken from a natural population of $L$. coquimbensis var alba had a somatic number of $2 n=14$, with a karyotype composed of ten metacentric chromosomes (m), two subtelocentric chromosomes (st), and two telocentric

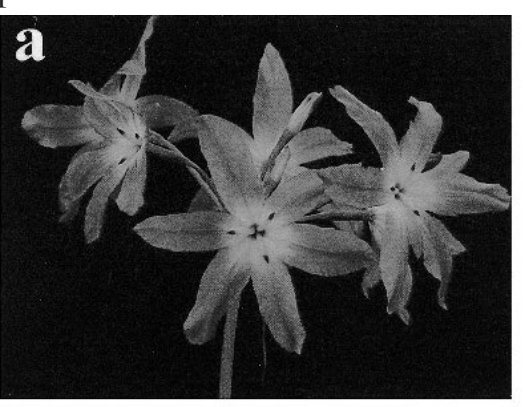

chromosomes (Fig. 4a). This is surprising because L. coquimbensis var alba shows a uniformly white flower phenotype which does not suggest a hybrid origin. We observed that when L. coquimbensis var alba are manually outcrossed they are highly infertile producing two to five seeds per fruit instead of the normal 40 to 60 seeds of other species. This suggests that it may be a triploid originating from a cross between a $2 n=10$ by a $2 n=18$.

Furthermore, a natural population composed of L. purpurea

Fig. 1. Floral phenotypes of Leucocoryne populations which are taxonomically unclassified: (a) L. sp. 'Alcones', (b) L. sp. 'Pichicuy', (c) L. sp. 'Talinay', (d) L. sp. 'Alicahue', (e) L. sp. 'Combarbalá', and (f) $L . s p$. 'Nague'.
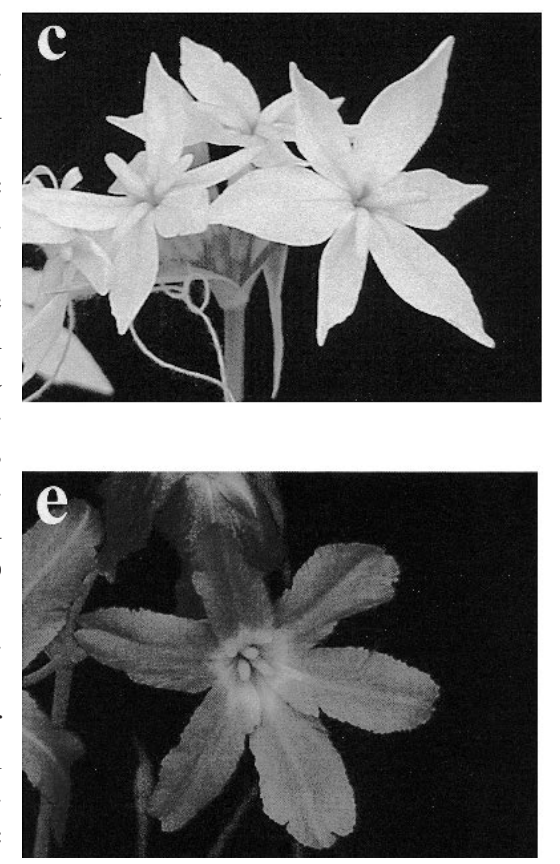
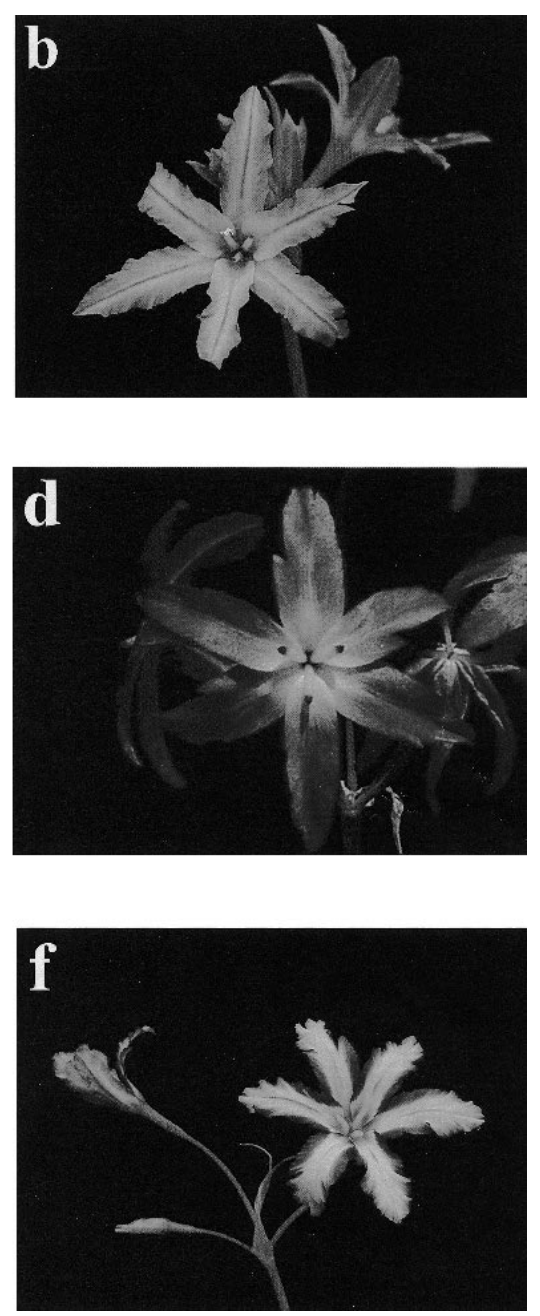
a

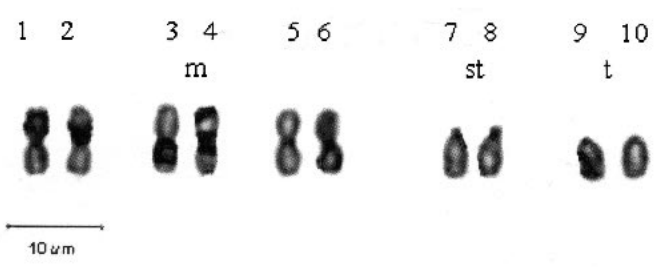

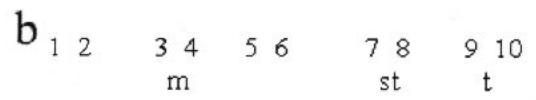

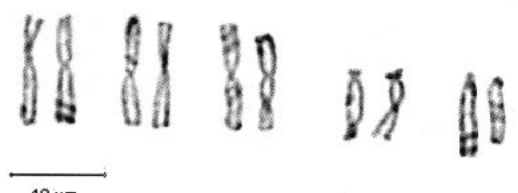

c

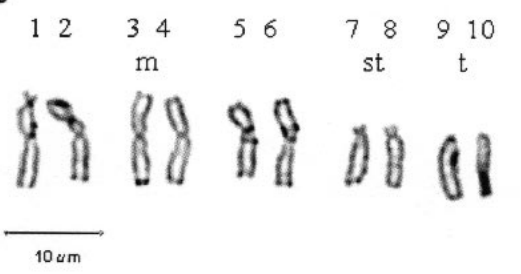

d

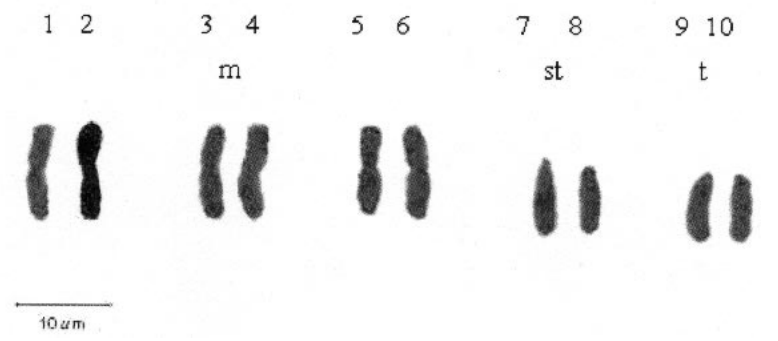

Fig. 2. Karyotypes of Leucocoryne species $2 n=10$, (a) L. sp. 'Ñague', (b) $L$. purpurea, (c) L. sp. 'Pichicuy', (d) L. sp. 'Alicahue'.

$(2 n=10)$, L. coquimbensis var coquimbensis $(2 n=18)$ and their putative hybrids, was observed to have individuals with $2 n=10$, $2 n=18,2 n=14$, and $2 n=22$, respectively (Fig. 4b-e). A similar population was observed by Moreno and Arancio (2001). Briefly, this shows that there is gene flow between species at different ploidy levels in Leucocoryne. These findings are discussed at length elsewhere (manuscript in preparation). $\begin{array}{llllllllllllllllll}\mathrm{a} & 2 & 3 & 4 & 5 & 6 & 7 & 8 & 9 & 10 & 11 & 12 & 13 & 14 & 15 & 16 & 17 & 18 \\ \mathrm{~m} & & & & & & & & & & & & & & & & & \end{array}$

$816 \log 888889888$ er us

$10 u \mathrm{~m}$

b

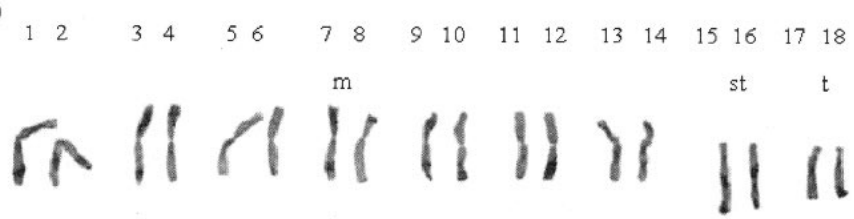

$10 \mathrm{em}$

$\mathrm{c}_{1}$

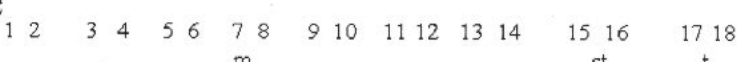

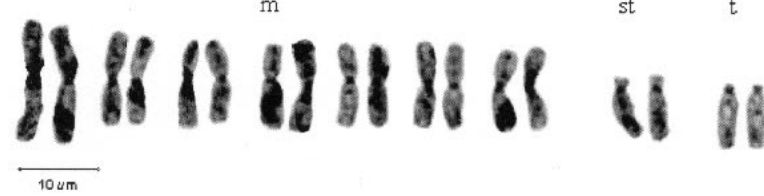

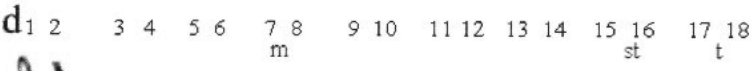

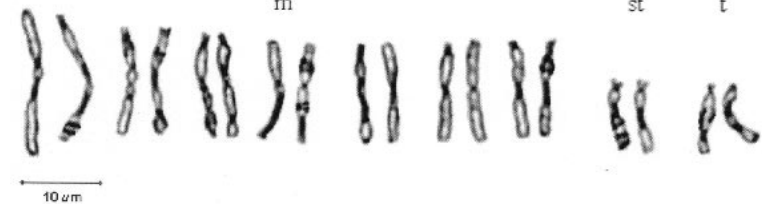

e

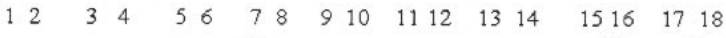

$\mathrm{m}$ sm st

1818848888881 1800

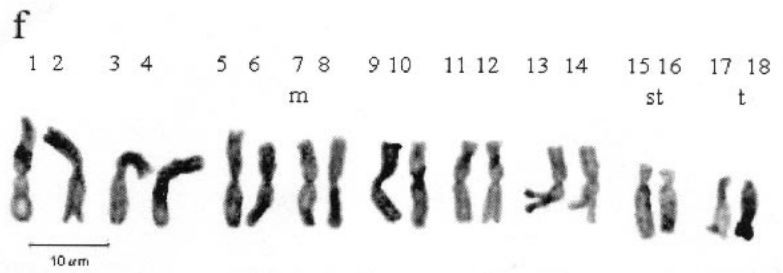

Fig. 3. Karyotypes of Leucocoryne species $2 n=18$ : (a) L. narcissoides, (b) L. coquimbensis var coquimbensis, (c) L. ixioides, (d) L. sp. 'Talinay', (e) L. sp. ‘Alcones', f L. sp. 'Combarbalá'.

Further studies are underway to investigate how these karyotypes originated. Unfortunately, a much-needed revision of this genus has not been carried out because of the great degree of difficulty posed by its ample genetic variability for the shape and form of its flowers and the scarcity of plant taxonomists working in Chile. Nevertheless we are currently describing two new species and are developing molecular marker methods to study the phylogeny of the genus.

Although, the high level of genetic variability for the shape and 
a

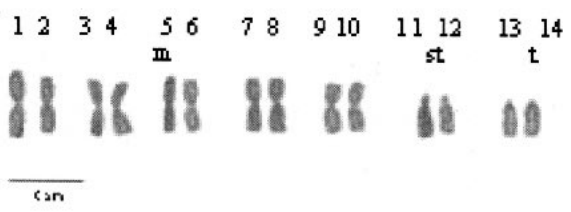

b

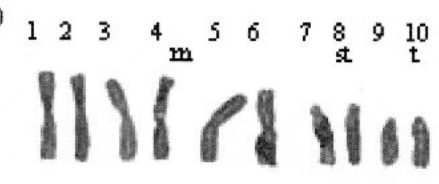

$10 \mathrm{um}$

c

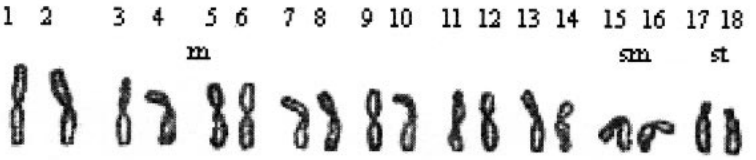

$\overline{10 \mathrm{2m}}$

d $\begin{array}{llllllllllllll}1 & 2 & 3 & 4 & 5 & 6 & 7 & 8 & 9 & 10 & 11 & 12 & 13 & 14\end{array}$ Ilinhifrissill $10 \mathrm{sm}$

e 1 II Hifi $10 \mathrm{~mm}$

Fig. 4. Karyotypes of L. coquimbensis var alba and individuals derived from a hybrid population of L. purpurea and L. coquimbensis var coquimbensis: (a) L. coquimbensis var alba $(2 n=14)$, (b) Leucocoryne with normal complement $2 n=10$, (c) Leucocoryne with normal complement $2 n=18$, (d) L. sp. $2 n=14$, and (e) L. sp. $2 n=22$.

form of its flowers, and the genetic flow between species, may pose a challenge to taxonomists and evolutionists, this genus is of great value for the development of unique ornamental cut flowers or potted plants. The bulbs used for these analyses are maintained in active growth as part of a large collection of Leucocoryne germplasm collected in $>40$ sites from all over Chile.

\section{Literature Cited}

Bahamondes, N. and V. Labarca. 1994. Citogenética y probables mecanis-
Table 2. Chromosome number of Leucocoryne species; $\mathrm{m}=$ metacentric chromosome, $\mathrm{sm}=$ submetacentric chromosome, $\mathrm{st}=$ subtelocentric chromosome $\mathrm{t}=$ telocentric chromosome.

\begin{tabular}{|c|c|c|}
\hline Species & $2 n$ & $\begin{array}{l}\text { Idiogramatic } \\
\text { formule }\end{array}$ \\
\hline L. narcissoides ${ }^{\mathrm{Z}}$ & 18 & $14 \mathrm{~m}+2 \mathrm{st}+2 \mathrm{t}$ \\
\hline L. coquimbensis var coquimbensis ${ }^{\mathrm{z}}$ & 18 & $14 \mathrm{~m}+2 \mathrm{st}+2 \mathrm{t}$ \\
\hline L. ixioides ${ }^{\mathrm{y}}$ & 18 & $14 \mathrm{~m}+2 \mathrm{st}+2 \mathrm{t}$ \\
\hline L. purpureay & 10 & $6 \mathrm{~m}+2 \mathrm{st}+2 \mathrm{t}$ \\
\hline L. sp. Nague z & 10 & $6 \mathrm{~m}+2 \mathrm{st}+2 \mathrm{t}$ \\
\hline L. coquimbensis var alba ${ }^{\mathrm{x}}$ & 14 & $10 m+2 s t+2 t$ \\
\hline L. sp. Talinay & 18 & $14 m+2 s t+2 t$ \\
\hline L. sp. Alcones ${ }^{\mathrm{x}}$ & 18 & $14 \mathrm{~m}+2 \mathrm{sm}+2 \mathrm{st}$ \\
\hline L. sp. Combarbaláx & 18 & $14 \mathrm{~m}+2 \mathrm{st}+2 \mathrm{t}$ \\
\hline L. sp. Pichicuy ${ }^{\mathrm{x}}$ & 10 & $6 \mathrm{~m}+2 \mathrm{st}+2 \mathrm{t}$ \\
\hline L. sp. Alicahue & 10 & $6 m+4 t$ \\
\hline
\end{tabular}

${ }^{2}$ Chromosome numbers confirmation, reported by Bahamondes and Labarca (1994).

yChromosome numbers confirmation, reported by Crosa (1988).

xNewly chromosome numbers described by us.

mos de evolución en especies de los géneros Leucocoryne y Pabellonia (Alliaceae). MS thesis. Univ. La Serena, La Serena, Chile.

Cave, M. 1939. Macrosporogenesis in Leucocoryne ixioides Lind. Citol. 8: 407-411.

Crosa, O. 1988. Los cromosomas de nueve especies del género chileno Leucocoryne Lindley, (Alliae-Alliacea). Bol. Fac.de Agronomía. Uruguay. Invest. 17:1-12.

Dyer, E. 1963. The use of lacto-propionic orcein in rapid squash methods for chromosome preparations. Stain Technol. 38:85-90.

Engler, A. 1964. Syllabus der Planzenfamilien. Gebruder Borntrager, Berlin.

Hutchinson, J. 1959. The families of flowering plants. Monocotyledones, vol. II.

Hayward, W. 1940. Leucocoryne as a pot plant. Herbertia 7:205.

Kroon, G. 1989. Evaluatie van Leucocoryne als nieuwe snijbloem. Prophyta 43:15-16.

Levan,A., K. Fredga, and A. Sandberg. 1964. Nomenclature for centromeric position on chromosomes. Hereditas 52:201-220.

Mansur, L. 2002. Ciclo de vida, autoincompatibilidad y plasticidad genética en diseño y color de sus flores, p. 9-15. In: Leucocoryne, un género nativo chileno y su uso como planta de jardín. 1st ed. REIMCO Ltda., Viña del Mar, Chile.

Moreno, R. and G. Arancio. 2001. Posibles híbridos naturales entre dos especies del género Leucocoryne. Gayana Botánica 58:86.

Ohkawa, K., H. Kim, E.Nitta, and Y. Fukazawa. 1996. Storage temperature and duration affect flower bud development, shoot emergence and flowering of Leucocoryne coquimbensis F. Phil. J. Amer. Soc. Hort. Sci.. 123:586-591.

Quezada, M. and C. Marticorena. 1976. Pabellonia, nombre nuevo para Chrysocoryne Zöellner (Alliaceae). Bol. Soc. Biol. Concepción 50: 219.

Rahn, K. 1998. Alliaceae, p. 70-78. In: K. Kubitzki (ed.). Flowering plants, Monocotyledons: Lilianae (except Orchidaceae). Springer Verlag, Berlin, Germany.

Rojas, I. and L. Mansur. 2001. Determinación de la compatibilidad reproductiva de una especie y dos ecotipos del género Leucocoryne en dos condiciones ambientales. Décima Tercera Reunión Nacional de Botánica de la Sociedad de Botánica de Chile, La Serena, IV Region, Chile.

Zöellner, O. 1972. El género Leucocoryne. Anales del Museo de Historia Natural 5:9-83. 